\title{
Article
}

\section{Appraisal of Nuclear Energy as an Alternative Option in South Africa's Energy Scenario: A Multicriteria Analysis}

\author{
Solomon Eghosa Uhunamure ${ }^{1, *(\mathbb{D})}$, Ephraim Bonah Agyekum ${ }^{2, *(\mathbb{D})}$, Olatunde Samod Durowoju ${ }^{3} \mathbb{C}$, Karabo Shale ${ }^{1}$, \\ Nthaduleni Samuel Nethengwe ${ }^{3}$, , Georges-Ivo Ekosse Ekosse ${ }^{3,4}$ and Tomiwa Sunday Adebayo ${ }^{5}$ (D) \\ 1 Faculty of Applied Sciences, Cape Peninsula University of Technology, P.O. Box 652, Cape Town 8000, South Africa; \\ shalek@cput.ac.za \\ 2 Department of Nuclear and Renewable Energy, Ural Federal University Named after the First President of \\ Russia Boris Yeltsin, 19 Mira Street, 620002 Ekaterinburg, Russia \\ 3 Faculty of Science, Engineering and Agriculture, University of Venda, P.O. Box X5050, \\ Thohoyandou 0950, South Africa; olatunde.durowoju@univen.ac.za (O.S.D.); \\ nthaduleni.nethengwe@univen.ac.za (N.S.N.); georges-ivo.ekosse@univen.ac.za (G.-I.E.E.) \\ 4 Directorate of Research and Innovations, University of Venda, P.O. Box X5050, Thohoyandou 0950, South Africa \\ 5 Department of Business Administration, Faculty of Economics and Administrative Sciences, \\ Cyprus International University, Northern Cyprus Via Mersin 10, 99670 Nicosia, Turkey; twaikline@gmail.com \\ * Correspondence: uhunamures@cput.ac.za (S.E.U.); agyekum@urfu.ru (E.B.A.)
}

check for

updates

Citation: Uhunamure, S.E.; Agyekum, E.B.; Durowoju, O.S.; Shale, K.; Nethengwe, N.S.;

Ekosse, G.-I.E.; Adebayo, T.S

Appraisal of Nuclear Energy as an Alternative Option in South Africa's Energy Scenario: A Multicriteria Analysis. Appl. Sci. 2021, 11, 10349. https://doi.org/10.3390/app112110349

Academic Editor: Andreas Sumper

Received: 8 October 2021

Accepted: 29 October 2021

Published: 3 November 2021

Publisher's Note: MDPI stays neutral with regard to jurisdictional claims in published maps and institutional affiliations.

Copyright: (c) 2021 by the authors. Licensee MDPI, Basel, Switzerland. This article is an open access article distributed under the terms and conditions of the Creative Commons Attribution (CC BY) license (https:// creativecommons.org/licenses/by/ $4.0 /)$.

\begin{abstract}
South Africa is being confronted with an irregular power supply, leading to persistent load shedding due to aged and unreliable coal-fired power plants. Connected with coal as a generating source for electricity from fossil fuels are environmental concerns such as emissions of greenhouse gases and climate change impacts. Nuclear energy can allay the country's dependence on coal as a source of energy. This article, therefore, reviews the feasibility of nuclear energy using a multicriteria analysis technique. A combination of Strengths, weaknesses, Opportunities, and Threats (SWOT) analysis and Analytical Hierarchy Process (AHP) was used to evaluate the external and internal factors that could either positively or negatively affect the country's nuclear energy expansion drive. From the analysis, the country's enabling laws and regulatory framework recorded the highest score of $39.2 \%$ under the strengths for the sector. In the case of the weaknesses, the high cost of construction and long construction framework recorded the highest weight, of 50.47\%. Energy export and demand under the opportunities recorded a weight of 52.09\%, ranking it as the highest opportunity for the sector. Seismic events were identified as the biggest threat for nuclear power expansion in the country, and the experts assigned a weight of $42.5 \%$ to this factor.
\end{abstract}

Keywords: nuclear energy; South Africa; multicriteria analysis; Analytical Hierarchy Process; SWOT analysis

\section{Introduction}

South Africa is ranked as the fifth most populous country in Africa, and the recent projection in 2019 estimates the population at 58.5 million [1]. The catalyst for the economic development and growth of any economy is energy. It is an indisputable fact that one of the key constituents to the development of South Africa is its energy potentials [2]. However, in generating energy, the country relies heavily on its large coal deposit, which is a fossil fuel product [3]. The abundance of coal and the well-established infrastructure have allowed the country to generate electricity at a cheaper cost when compared to the infrastructural development of other energy sources [3]. Nevertheless, this has not translated to the total availability of energy to all its citizens. In 2018, it was estimated that more than 1.5 million households, representing about 5 million South Africans, are still without electricity [4]. It is expected that the electricity demand will increase from $245 \mathrm{TWh}$ in 2015 to 522 TWh in 2050, representing an annual growth rate of 2.3\% [5]. 
The country is regarded as one of the fast-developing economies in the world [6]. Although the speed of electrification in the country has increased, the backlogs have been challenged by the aging coal-fired stations, resulting in belt and structural damages, which require increased maintenance downtime, and even environmental consequences of greenhouse gas emissions and climate change impacts [3]. These effects have prompted the government to look inwards into other energy sources as an alternative to coal. One of the considered energy options is the exploitation of nuclear power, which is expected to help decarbonize the very intensive coal-powered source. In the world today, after hydropower, the second-largest source of low-carbon energy used in electricity production is nuclear power [7]. In the course of operation, near-zero greenhouse gases are emitted by nuclear power plants. According to the IEA [8], over the past 50 years, more than 60 gigatonnes of greenhouse gas emissions have been reduced, which, globally, translates to almost two years' worth of energy-related emissions.

Around the world, nuclear power accounts for $10 \%$ of the electricity production, representing one-third of low-carbon electricity. There are about 440 nuclear power reactors in 30 countries, including South Africa, that are in operation currently. In 19 countries, there are 54 reactors under construction, which includes four countries building their first reactors [7]. This article was, therefore, objectively driven by evaluating the desirability of increasing the nuclear power in the country, thereby enhancing the necessity to reduce greenhouse gases from fossil fuels' consumption, the need to upsurge the energy share in the country's energy mix, and the necessity to ameliorate sustainable development and growth through the provision of clean energy sources using a multicriteria analysis approach on the provision of nuclear energy in the country. Although studies such as Ishola et al.'s [9] and Agyekum et al.'s [10] looked at the nuclear energy environment, such as Ghana's and Nigeria's, they did not combine it with any multicriteria analysis. This study moves a step beyond the mere identification of the various factors under the SWOT analysis by using the Analytical Hierarchy Process to assign weights to the various identified factors using input from experts in the sector. This approach gives more detail to the various identified factors and also presents the most pressing factors to be resolved during decision making.

The study is organized as follows. The current energy status of South Africa is presented in Section 2. The country's roadmap for nuclear energy is presented in Section 3. Section 4 looks at the cost comparison of nuclear and other alternative sources of energy generation. The method used for the study is presented in Section 5. The results and discussion are presented in Section 6. The conclusion is presented in Section 7.

\section{Current Energy Status in South Africa}

Coal is the dominant source of energy in South Africa, and it is in abundance and cheap. In the world, the country has the fifth largest coal reserves, and they are estimated at around 66.7 billion tons [11]. Coal is regarded as among the lowest in terms of energy cost in the world, and, by international standards, the country's coal deposits are comparatively shallow with thick steams, which allow mining to be inexpensive and easy. Presently, by production and supply rates, it is estimated that the coal reserves cannot exceed 50 years more [3]. Significantly, it is unlikely that the dependence on coal by South Africa is going to change in the next two decades due to the lack of a suitable substitute for coal. Apart from the extensive use of coal in the domestic economy, in 2016, South Africa exported around $24 \%$ of coal and only imported around 1\% [5]. Still dominant in the country are coal-fired power stations in terms of generating power until other sources such as renewables and nuclear are ascertained. In 2018, a major contribution from the coal-powered stations makes up $83 \%$ of the energy mix from the generating capacity. By combination and contribution, the maximum generating capacity by other power stations constituted a total of $17 \%$, with gas turbines accounting for $6 \%$, pumped storage schemes $6 \%$, and nuclear power stations $3 \%$. Wind farm generation at $100-\mathrm{MW}$ capacity was insignificant compared to other sources [12]. 
Approximately $40 \%$ of the total electricity supplied on the continent is from South Africa [13]. The electricity sector is controlled by the national utility Eskom, which is the primary supplier of electricity and generates around $90 \%$ of the total electricity consumed in the country [11]. The other balance is supplied by private generators, redistributors, and municipalities. Directly, Eskom sells power to some 6 million residential households, 2703 industries, 81,638 agricultural, and 51,848 commercial entities, with its over 28,000 km of transmission lines, which span the entire country. In 2016, the total electricity produced amounted to $91 \%$, while $3 \%$ was the country's net export [13]. A number of hydro, gas-fired, coal-fired, and pumped storage power stations are owned by Eskom. Aside from coal, which contributes around $69 \%$ of the total energy supply, other sources include gas, $3 \%$; renewables and waste, $11 \%$; crude oil, 14\%; and nuclear energy, 3\% [12].

\section{Nuclear Energy Road Map in South Africa}

The journey toward the development of large-scale renewable technologies in South Africa demonstrates a heterogeneous combination of government intervention policies, which unite with market forces to convey an unparalleled world-class energy program [3]. The country's state of energy sources' reports historically dates back through the chronicles of individual developers and decision makers who influenced the direction of energy policy and eventually the implementation in various ways. Over and above the rich coal deposit, South Africa is fortunate to be well endowed with non-depletable energy resources. The coal reserves are mainly found in the northeastern part of the country (Mpumalanga), whereas much of the load is in Durban and on the coast close to Cape Town. In the mid-1970s, the government decided to build approximately 1800 MWe of the nuclear power plant in Koeberg, near Cape Town, because the movement of coal or electricity over a long distance was inefficient [14].

Additionally, the Pebble Bed Modular Reactors (PBMRs) and Small Modular Reactors (SMRs) were developed by a South African company from 1994 till 2009. Included in the facilities were a gas turbine and heat transfer labs at a high-pressure temperature helium test rig to reduce the temperature from $950{ }^{\circ} \mathrm{C}$ to $800^{\circ} \mathrm{C}$ as well as a prototype fuel fabrication plant, which included kernel production, coated particle production, fuel sphere production, and quality control [15]. Inherently, the PBMRs are well characterized by safety features, meaning no equipment failure or human error can cause an accident that would be detrimental to the public [15]. Nevertheless, in 2010, the government announced that it was no longer funding the development of the PBMRs and SMRs and stated that it was considering a $75 \%$ staff cut off. Among the challenges faced by the government were that no investor or customer was found to be interested in PBMRs and SMRs, several unresolved technical issues resulted in substantial costs increment, there was no support from the international banks to grant loans to finance the project, and also the 2008 report about the major problems of the German pebble bed reactor, which greatly discouraged investors [16,17]. The South African government engagement in the New Generation Nuclear Plant (NGNP) came to an end in 2010 when the major consortium withdrew from the PBMRs and SMRs projects [16,17], which presently remain in a state of care and maintenance with nine staff members [15].

To keep the lights on in a sustainable manner, there is a rekindled interest in revitalizing nuclear energy in the country, which is not unconnected with the aging coal plants, which are now failing due to an increase in energy demand, thus resulting in incessant load shedding in the country [18].

To enhance the optimum utilization of the abundant renewable energy potential in the country, the government established several outstanding policies, which can be traced back to the 1996 constitution. These were effectively translated into different working documents and notably include the 1998 White Paper on Energy Policy, the 2003 White Paper on Renewable Energy, and the 2011 National Climate Change Response White Paper Policy. The National Planning Commission, in 2011, completed the National Development Plan, which arrays the encompassing long-term vision for the growth and development 
of renewable energy in the country [3]. The South African nuclear sector is governed mainly by the Nuclear Energy Act 46 of 1999 and the National Nuclear Regulatory Act 47 of 1999. The Department of Energy is saddled with the responsibility of administering these acts. Through these acts, it is expected that the introduction of 9600 MW of electricity will be added to the grid, which presently generates about 58,095 megawatts (MW), and change the energy scenario of the country by the year 2030. Two nuclear reactors producing electricity in South Africa that were designed and supplied by Framatome are located in Koeberg, with the details highlighted in Table 1 [14].

Table 1. Koeberg Plant 1 and Koeberg Plant 2 [14].

\begin{tabular}{|c|c|c|c|c|c|c|c|c|}
\hline \multicolumn{9}{|c|}{ Koeberg Plant 1} \\
\hline Reactor Type & Model & $\begin{array}{l}\text { First Grid } \\
\text { Connection }\end{array}$ & Owner & Operator & $\begin{array}{c}\text { Net } \\
\text { Capacity }\end{array}$ & $\begin{array}{l}\text { Gross } \\
\text { Capacity }\end{array}$ & $\begin{array}{l}\text { Thermal } \\
\text { Capacity }\end{array}$ & $\begin{array}{c}\text { Net Capacity } \\
\text { Design }\end{array}$ \\
\hline $\begin{array}{l}\text { Pressurized Water } \\
\text { Reactor (PWR) }\end{array}$ & $\mathrm{CP} 1$ & 1984-04 & Eskom & Eskom & $\begin{array}{c}930 \\
\text { MWe }\end{array}$ & 970 MWe & $2775 \mathrm{MWt}$ & $921 \mathrm{MWe}$ \\
\hline \multicolumn{9}{|c|}{ Koeberg Plant 2} \\
\hline Reactor Type & Model & $\begin{array}{l}\text { First Grid } \\
\text { Connection }\end{array}$ & Owner & Operator & $\begin{array}{c}\text { Net } \\
\text { Capacity }\end{array}$ & $\begin{array}{l}\text { Gross } \\
\text { Capacity }\end{array}$ & $\begin{array}{l}\text { Thermal } \\
\text { Capacity }\end{array}$ & $\begin{array}{c}\text { Net Capacity } \\
\text { Design }\end{array}$ \\
\hline $\begin{array}{c}\text { Pressurized Water } \\
\text { Reactor (PWR) }\end{array}$ & $\mathrm{CP} 1$ & 1985-07 & Eskom & Eskom & $\begin{array}{l}930 \\
\mathrm{MWe}\end{array}$ & 970 MWe & $2775 \mathrm{MWt}$ & $921 \mathrm{MWe}$ \\
\hline
\end{tabular}

Nuclear energy is created from splitting uranium atoms through a process referred to as fission. By this course, through a chain reaction, a large amount of energy is released as heat, which is generated to produce steam, then used by a turbine generator to produce electricity [19]. The switch from conventional energy sources, which are crude oil and coal, to nuclear energy is anticipated to lessen the energy demand pressure in developed and developing countries [20].

The South African government, through the Department of Energy, in 2014 signed a Memorandum of Understanding with the State Atomic Energy Corporation of Russia (ROSATOM), as a strategic partner in the development of nuclear energy in the country. However, since the 1990s, ROSATOM has been engaged in the supply of enriched uranium products to the Koeberg Nuclear Plant. In 2015, two Memoranda of Understanding were also signed in the areas of personnel training and public awareness enhancement in the nuclear energy sector of South Africa [12]. Furthermore, some African countries have also entered into a partnership with ROSATOM in the development and deployment of the nuclear energy program. These countries, in addition to South Africa, are Nigeria, Ghana, Namibia, Uganda, Zambia, and Tanzanian [21]. The South African government has set the following target for its energy generation mix by 2030: nuclear energy, $17 \%$; coal, $12.9 \%$; and hydro, concentrated solar power (CSP), solar PV, wind, and gas are also targeted to form $7 \%, 2 \%, 15 \%, 16.3 \%$, and $12.9 \%$, respectively [12].

\section{Cost Comparison of Nuclear Energy versus Other Alternatives}

The inclusion of nuclear energy in the energy mix will lead to an increase in the installed energy capacity and also the reduction of greenhouse gas emissions into the environment as a way of combating climate change. Nuclear technology, unlike other alternative sources, uses uranium in generating power. Lazard's 2018 Levelized cost of energy components' (LCOEC) estimation for different sources of energy is outlined in Table 2. This estimation undeniably puts nuclear power production for energy as one of the expensive one compared to other options. Nonetheless, in the context of environmental pollution, principally from fossil fuels, the exploration of nuclear energy is a better alternative due to its limited carbon dioxide emissions. Additionally, there is high uncertainty regarding energy policies that could rule out some technologies as a result of the high recompense rate demanded by investors in order to pay for perceived high- 
level risk concerning those technologies [22]. Although relatively cheaper, the unevenness of renewable energy sources such as solar and wind makes them disadvantageous over nuclear energy.

Table 2. Levelized Cost of Energy Components: Low and High End [10].

\begin{tabular}{ccc}
\hline Type of Technology & Levelized Cost of Energy Components (\$MWh) \\
\hline Alternative Energy & Low End & High End \\
\hline Solar PV-Rooftop Residential & $151-160$ & $245-267$ \\
Solar PV-Community & $67-73$ & $135-145$ \\
Solar thermal tower with storage & $78-98$ & $164-181$ \\
Fuel cell & $45-103$ & $83-152$ \\
Geothermal & $46-71$ & $76-111$ \\
Wind & $23-29$ & $45-56$ \\
\hline Conventional Energy & & \\
Gas peaking & $108-152$ & $145-206$ \\
Nuclear & $87-112$ & $162-189$ \\
Coal & $41-60$ & $110-143$ \\
Gas combined cycle & $16-41$ & $47-74$ \\
\hline
\end{tabular}

\section{Methodology}

The study adopted both quantitative and qualitative means of evaluating the country's nuclear energy sector. This study adopted a multicriteria decision-making approach, i.e., the SWOT analysis approach, which is an acronym for strengths, weaknesses, threats, and opportunities, and the Analytical Hierarchy Process (AHP) to scrutinize the disposition of South Africa's nuclear energy. The flowchart for the study is presented in Figure 1. The main source of information about the various factors considered was from the literature that was reviewed, either from published peer-reviewed articles, government documents, or views from experts in the country's energy sector.

\subsection{SWOT Analysis}

The appraisal of SWOT analysis is founded on the internal (strengths and weaknesses) and external (opportunities and threats) measures. Originally, the SWOT technique was applied in the business and marketing environments. Today, it is been applied in other research disciplines including the field of energy [23]. Widely accepted in energy-related research in evaluating salient factors is the SWOT analysis tool. Several authors have applied this technique in eliciting findings in the field of energy. Some include a study by Kamran et al. [24], which applied the SWOT technique in evaluating the empowerment of the renewable energy sector in Pakistan. Chen et al. [25] used SWOT analysis as a tool in assessing the advancement and potential of green energy in South Korea, Japan, and Taiwan. Ishola et al. [9] applied the tool in the assessment of Nigeria's nuclear power exploration planning. The tool was also used by Hamami et al. [26] in analyzing the key issues in the Tunisian energy sector. The application of SWOT analysis was conducted by Lei et al. [27] in assessing Africa's photovoltaic solar power in comparison to China. The deployment of SWOT analysis is advantageous on the grounds that it can be conducted with little or no cost. It also lays emphasis on crucial factors that could affect the smooth execution of a business or project. The data for this study were sourced from relevant, existing literature and working documents on nuclear energy development in South Africa and around the world. The significance of this study is to explore and ensure strategic decision making regarding nuclear energy options in South Africa that are expected to be of immense value to the decision makers. 


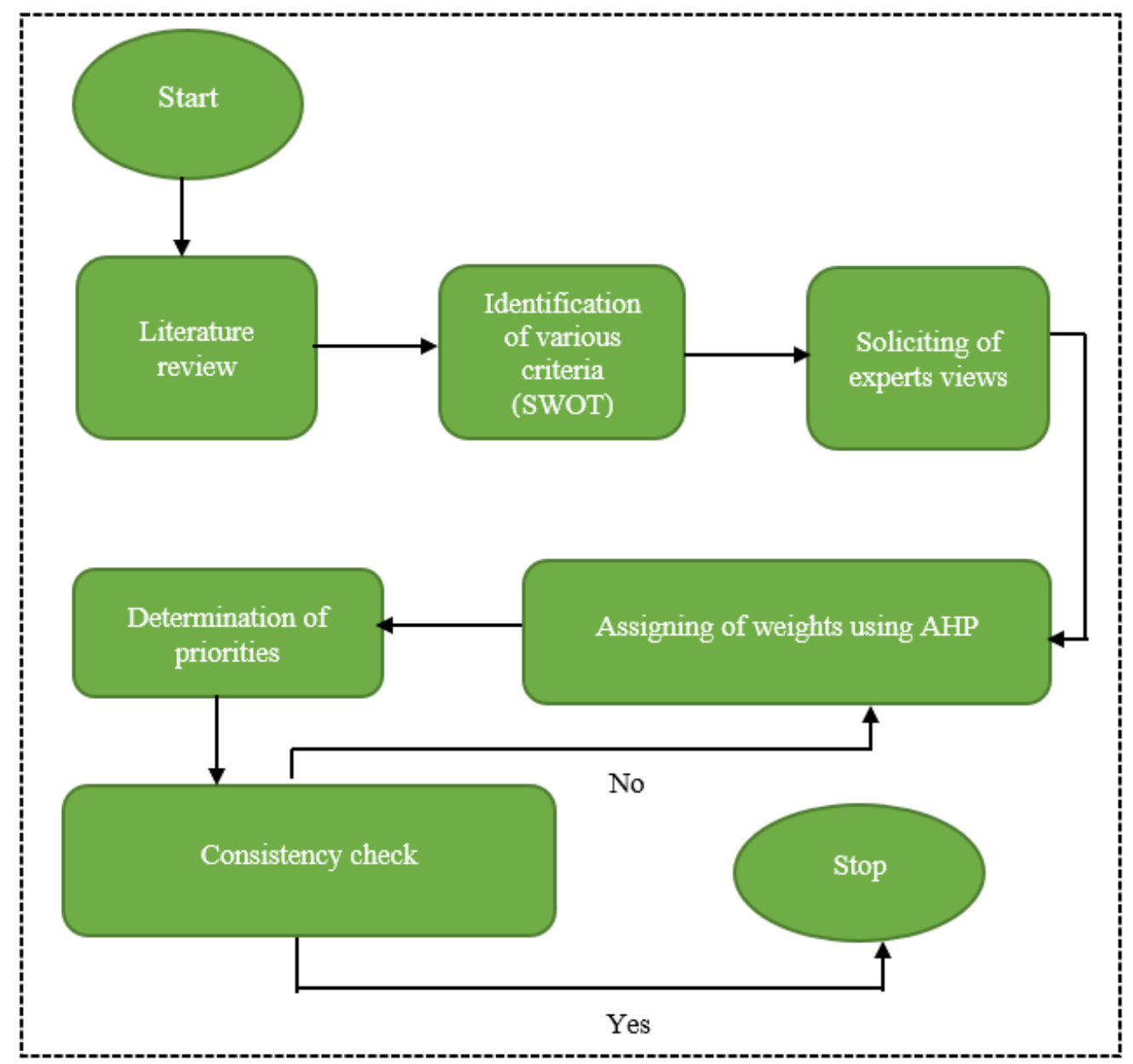

Figure 1. Flowchart for the study.

\subsection{Analytical Hierarchy Process}

The AHP method was developed by Saaty $[28,29]$. This method has the potential to lessen complex decisions to a series of pairwise comparisons. It can check the consistency of individual decisions to reduce the biases that may exist in the decision-making process [30]. Let $M=\left[C_{i j}\right]$ be a pairwise comparison that shows the intensity of an expert's preference between factors or individual criteria that are to be considered. The judgement matrix for $n$ criteria for a particular study can be described as presented in Equation (1) [31,32]. The criterion weight for each factor identified under each of the quadrants of the SWOT analysis was calculated using Saaty's fundamental scale, which is also recognized as the 9-point scale, shown in Table 3.

$$
M=\left|\begin{array}{ccccc}
c_{11} & c_{12} & \ldots & c_{1(n-1)} & c_{1 n} \\
c_{21} & c_{22} & \ldots & c_{2(n-1)} & c_{2 n} \\
\vdots & \vdots & \ddots & \vdots & \vdots \\
c_{n 1} & c_{n 2} & \ldots & c_{n(n-1)} & c_{n n}
\end{array}\right|
$$

where $C_{i j}$ represents the comparative importance of the criterion $C_{i}$ over $C_{j}$.

A total of 16 experts in the South African Nuclear energy and power sector were consulted to rank the various identified criteria. To consolidate the experts' judgments, the geometric mean (GM) method was used [33]. For this study, the priorities are represented by $p_{i}$ for every expert, who are then assessed using the row geometric mean method (RGMM). The following mathematical relations, Equations (2)-(4), were used [34-37]. 
We evaluated:

$$
r_{i}=\exp \left[\frac{1}{N} \sum_{j=1}^{N} \ln \left(c_{i j}\right)\right]=\left(\prod_{i=1}^{N} c_{i j}\right)^{1 / N}
$$

Then we normalized it using Equation (3).

$$
p_{i}=\frac{r_{i}}{\sum_{i=1}^{N} r_{i}}
$$

Equation (4) was used to estimate the geometric consistency index (GCI).

$$
G C I=\frac{2 \sum_{i<j} \ln c_{i j}-\ln \frac{p_{i}}{p_{j}}}{(N-1)(N-2)}
$$

\begin{tabular}{|c|c|c|}
\hline The Intensity of the Weight & Description & Implication \\
\hline 1 & Equally significant & Equal contribution by two criteria to the objectives \\
\hline 3 & Moderately more significant & One criterion is a little preferred over the other \\
\hline 5 & Strongly more significant & One criterion strongly preferred over the other \\
\hline 7 & Very strongly more significant & One criterion favoured very strongly over the other \\
\hline 9 & Very more significant & $\begin{array}{l}\text { The evidence favouring one criterion over another is } \\
\text { of the highest possible order of affirmation }\end{array}$ \\
\hline \multirow[t]{2}{*}{$2,4,6,8$} & Intermediate values & $\begin{array}{c}\text { Employed to represent a compromise between the } \\
\text { priorities listed above }\end{array}$ \\
\hline & Reciprocals & $\begin{array}{l}\text { If criteria } i \text { has one of the above non-zero numbers } \\
\text { assigned to it when compared to criteria } j \text {, then } j \text { has } \\
\text { the reciprocal value when compared with criteria } i\end{array}$ \\
\hline
\end{tabular}

Table 3. A nine-point relative importance scale was used for the AHP developed by Saaty [38].

\section{Results and Discussion}

This section provides the outcome of the literature review and interviews. It includes discussions on the various factors identified and the various weights assigned to them by the consulted experts, as presented in Table 4 .

Table 4. Summary of the factors discussed under each quadrant.

\begin{tabular}{cc}
\hline Strengths & Weaknesses \\
\hline Enabling laws and regulatory framework (S1) & Costly to build and lengthy construction time frame (W1) \\
\hline Uranium mining (S2) & Incessant court cases (W2) \\
\hline $\begin{array}{c}\text { Experience with the operations of an NPP and management of } \\
\text { radioactive waste (S3) }\end{array}$ & Porous border system (W3) \\
\hline Reduction in GHGs' emissions (S4) & Inadequate manpower/technical know-how (W4) \\
\hline Strong partnerships' integration (S5) & Threats \\
\hline High energy density (S6) & Seismic events (T1) \\
\hline Opportunities & Water availability (T2) \\
\hline Energy export and demand (O1) & Incessant court cases (T3) \\
\hline Climate change awareness (O2) & Domination of fossil fuel (T4)
\end{tabular}




\subsection{Qualitative Analysis}

6.1.1. Strengths

Enabling Laws and Regulatory Framework

The use of nuclear energy, including the potential it affords mankind, is sometimes apparently in contrast with the perceived likelihood of the proliferation of nuclear weapons and warheads. These different perceptions are understandable in the sense that expertise, materials, and knowledge that are requisite in producing nuclear energy are no different than those for producing nuclear power. In line with this, the international community places emphasis that focuses on guaranteeing the peaceful use of nuclear production [39]. For this reason, the South African government set up the National Nuclear Regulator (NNR) to regulate every aspect of the nuclear program in the country. The regulation, together with other nuclear acts, ensures the "provision and maintenance of an effective and efficient national regulatory framework for the protection of people, property and the environment against nuclear damage". The NNR is primarily mandated to monitor and enforce regulatory safety standards for the achievement of safe operating conditions, prevention of nuclear accidents, or mitigation of nuclear accident consequences, resulting in the protection of workers, the public, property, and the environment against the potentially harmful effects of ionizing radiation or radioactive material. To fulfil its mandate, the NNR advocates for the development and maintenance of appropriate regulatory frameworks for enforcing regulatory radiation safety standards that are consistent with the recommendations of the International Commission on Radiation Protection (ICRP) and the International Atomic Energy Agency (IAEA) [40].

\section{Uranium Mining}

The production of uranium in South Africa has largely been a by-product of copper or gold mining. Activities have been ongoing in exploiting the uranium-rich slurries from gold and copper mining in the country. Resource availability is paramount in decision making when planning for energy-generating technology [41]. Regarding nuclear power, the disposal of uranium in a certain place reduces the cost of running such facilities. Presently, there are over 400 tailings, dumps, and dam sites arising from the mining of gold in the Witwatersrand area of the Gauteng province, where most of the uranium is mined. Further tailings, dumps, and dams sites around the country are being re-treated to recover uranium [42].

Experience with the Operations of an NPP and Management of Radioactive Waste

Currently, South Africa is the only African country with an installed and operational nuclear power plant. The 900-MW PWR reactor is located some $30 \mathrm{~km}$ northwest of Cape Town [43,44]. The country's electricity utility, Eskom, owns the power station, and about $5 \%$ of the country's annual electricity generation comes from this facility. Additionally, Vaalputs serves as the waste disposal site for low and intermediate waste, whereas the high-level waste is kept in pools at the power station [43]. This comes as a strength since the country has gained experience in the use of a nuclear facility, which suggests that the country's plan to expand its generation from nuclear energy will come with relatively lesser challenges.

\section{Reduction in GHGs' Emissions}

The use of nuclear energy for electricity generation is considered cleaner compared to other traditional fuels such as fossil. In using nuclear power, greenhouse gases such as carbon dioxide and methane are deliberated, as by [45]. A nuclear advocacy group, the World Nuclear Association, revealed that, per gigawatt hour (GWh), the average emission of carbon dioxide is 29 tonnes, which is favorably compared with renewable energy sources such as wind, 26 tonnes per GWh and solar, 85 tonnes per GWh, and more favorably with fossil fuels such as coal, 888 tonnes per GWh, and ignite, 1054 tonnes per GWh. Roughly, 
nuclear produces less or the same emission as renewable energy and, thus, it is considered an environmentally friendly source of energy [45].

\section{Strong Partnerships' Integration}

The successful deployment of nuclear power production lies within strong partnerships and integration of manpower, which will guarantee the impetus to protect the use of nuclear power. Although, historically, South Africa has pursued self-sufficiency in its energy cycle, which is becoming a priority, the government has established notable partnerships to achieve its energy goal [46]. These prominent partnerships include Russia, China, Korea, and the United States of America. The South African government's agreement with Russia is in the provision of a strategic partnership in the development of nuclear power plants and waste management. A similar inter-governmental agreement was reached with China, which initiated the introductory phases for the potential utilization of Chinese nuclear technology in the country. The partnership integration with Korea and the United States of America is in the area of research and development. This is to facilitate development in the field of nuclear energy and radiation sciences and technology and to process source material, restricted material, and special nuclear material [47].

\section{High Energy Density}

Nuclear energy sources are endowed with higher energy density than fossil fuels and release a large amount of energy. The amount of energy released from nuclear fission is estimated to be 10 million times greater than the amount of energy released when fossil fuels are burned. This implies that the required amount of nuclear fuel from a nuclear power plant is much smaller when compared to the other power plants. Thus, nuclear power plants require low quantities of fuel to produce an enormous amount of energy and, therefore, help in contributing to the low cost of nuclear energy costs. One nuclear power plant can, therefore, produce thousands of megawatts of energy per hour [48].

\subsubsection{Weaknesses}

Costly to Build and Lengthy Construction Time Frame

Regardless of being comparatively inexpensive to operate, incredibly, the construction of nuclear power plants is expensive, and the cost keeps increasing. The operation is a relatively low-cost endeavor but constructing it in the first place is very expensive. For instance, from 2002 to 2008, the estimated cost of constructing a nuclear power plant increased from about $\$ 2$ billion- $\$ 4$ billion to $\$ 9$ billion, and the construction of power plants oftentimes surpasses their initial estimated cost during construction. Huge investments are necessary to build a nuclear plant, due to related costs such as the cost of installing a radiation containment system. Additionally, it takes several years to complete the construction of nuclear power plants because large infrastructures are required. The hitches of producing power from a nuclear power plant in a short time frame make it less favorable when compared to constructing electricity plants that run on traditional sources [49].

\section{Limited Fuel Availability}

One weakness confronting the reliance on nuclear power for energy production is the limited fuel availability it poses. Unlike fossil fuel, which is almost readily available in most countries, uranium, which is the source of nuclear energy, is a very scarce resource and exists only in a few countries. Even where available, permission is required from several international bodies and authorities before building a nuclear plant. Additionally, unless breeder reactors or nuclear fusion are created, the energy supply from nuclear plants can dry up, and this could affect the possibility of generating energy with nuclear power plants in the nearest future. It is ultimately considered as a weakness because, despite the very high price tag, nuclear power is envisaged as a temporal solution [45]. Furthermore, studies by Luderer et al. [50] and Sovacool [51] indicated nuclear as having limited fuel availability, 
whereas a study review by Shang et al. [52] indicated the abundance of uranium is in greater quantity particularly from phosphate rock.

\section{Risks of Nuclear Accidents}

There are very strict safety measures in place in any nuclear plant. Nevertheless, accidents can happen irrespective of the safety measures in place. Surrounding areas to a nuclear power plant can witness a disastrous impact from a nuclear meltdown. Some known events from such a catastrophe include the likes of Chernobyl, Three Mile Island in Pennsylvania, and the Fukushima disaster. In the occurrence of a nuclear meltdown, there are high chances of harmful radiation, which can leak and cause severe effects on the environment as well as human health. In the case of the 1986 incident in Chernobyl, thousands of deaths were recorded with an estimated range from 4000 to around 60,000 deaths. Additionally, more than 2 million people are still struggling with health-related problems due to the Chernobyl crisis [47]. Today, after more than 30 years, access is still limited in the 19-mile Chernobyl exclusion zone. However, these accidents are rare [53].

\section{Inadequate Manpower/Technical Know-How}

The backbone to the realization of any technology is adequate manpower and the technical know-how of using such technology. With regards to the exploration of nuclear power production, South Africa is constrained by manpower and, as such, agreed with several nuclear power developers to train some South African personnel. As part of the strategic agreement on nuclear power operations, 50 South Africans had to undergo training in China. Part of the training among others included the physical characteristics of nuclear power plants, material sciences, water chemistry, mechanical equipment, steam power conversion, nuclear island and conventional island equipment, control theories and radiation instrumentation, operation theories, and nuclear safety culture [18].

\subsubsection{Opportunities \\ Energy Export and Demand}

South Africa exports electricity to Lesotho, Namibia, Zimbabwe, Mozambique, Botswana, Zambia, and eSwatini. In 2016, an estimated 16.55 billion $\mathrm{kWh}$ of electricity was exported from the country [3]. The inclusion of nuclear energy in the country's energy mix will ensure the continuous exportation of energy as part of Gross Domestic Product earnings. Every sector of the South African economy, as well as the population, has continued to witness exponential growth. The general household survey in 2018 indicated that there has been a tremendous increase in households connected to the main electricity supply, increasing from $76.7 \%$ in 2002 to $84.7 \%$ in 2018 . This, however, still indicates a shortfall of $14.3 \%$ of households without connection to the nation's grid [4]. The socioeconomic growth continuously puts pressure on the already constrained power sector in meeting the required energy demand. Consequently, the integration of nuclear power in the energy sector should be considered as a worthwhile investment because the energy generated will lessen the burden of energy demand from the already constrained coal-fired plants.

\section{Climate Change Awareness}

Globally, most governments, including the South African government, are becoming more concerned by the impact of fossil-driven fuels, and are, therefore, looking for alternatives. These alternatives will be clean and devoid of environmental consequences. Globally, this notion has unlocked the integration of alternative energy options, such as nuclear power, to play an essential role in the energy mix of different countries [7]. Several countries, especially those generating energy from carbon-intensive sources, have pledged their support for the abatement of carbon. South Africa, as one of these countries, hosted the 2011 United Nations Climate Change Conference, tagged Conference of Parties (COP 17), where new treaties were established to limit the emissions of carbon [54]. 


\section{Foreign Investors' Partnership}

The expedition by the South African government to diversify its energy mix with the inclusion of nuclear energy has received interest from different countries. There is interest in infrastructural funding to advance the prospect of energy technology in the country and these prospects open the door to providing a solid platform for extensive future collaborations [55]. These investments in the nuclear energy sector will also pave the way for the supply of local chain provisions. Similar partnerships and agreements from foreign investors have created room for government loans in a build-own-operate model [20].

\section{Job Creation Potentials}

The ease of access to energy services, cost, and reliability play a key role in creating conditions for jobs and production as well as decent work. Improvement in the citizens' economic well-being is an important priority of sustainable development, as shown in Sustainable Development Goals (SDG) 8. A nuclear project has the potential to create several short- and long-term jobs in the areas of operations, contracting, and supply chain. Jobs concerning energy are normally categorized into induced, direct, and indirect jobs. Indirect jobs take into consideration the total number of people who are employed in areas that supply the energy project with goods and services, whereas direct employment includes the production as well as the delivery of energy products to the final user. Induced employment is associated with the spending that comes with both direct and indirect jobs (e.g., spending on salaries). For instance, it is estimated that in the United States of America each job that is directly created by a nuclear power plant that is newly built induces the creation of four extra indirect employments in the rest of the economy [56].

\subsubsection{Threats}

Seismic Events

The siting and construction of a nuclear power plant require the location to be free from natural disasters such as flooding, landslides, earthquakes, and tsunami [9]. South Africa is not a particular earthquake-prone country when compared to others. The country has, however, exhibited a unique distinction because the majority of its seismic activities are caused by deep-level mining. Over $80 \%$ of the recorded seismic activities in the country are all mining related. In the country, areas of deep-level gold and iron ore mining are potentially prone to earthquakes [57]. Occasionally and seasonally, and like most African countries, South Africa experiences some episodes of floods [58]. However, the probability of flooding affecting its nuclear site can be controlled by crucial geological and geographical assessments. Additionally, of concern from the seismic events is that the deployment of nuclear technology leads to the generation of radioactive waste. This could lead to radionuclide and heavy metal pollution resulting in acid mine drainage, in addition to creating radioactive waste, which is of great concern to the government.

\section{Water Availability}

Despite the long stretches of its coastline, measuring $3000 \mathrm{~km}$ south to the Atlantic and surrounded by several water bodies, South Africa is regarded as a water-stressed, water-scarce country [59]. The average rainfall is $465 \mathrm{~mm}$, far below the world average of $1200 \mathrm{~mm}$ [60]. Water is imported to South Africa from the Katse Dam, through the Lesotho Highlands Water Project [61]. Nuclear reactors require enough water to cool and steam the system before heat that is produced and converted to electricity is generated [62]. Presently, water scarcity is overwhelming in most parts of the country from industrial to households; thus, redirecting water for human consumption to power nuclear reactors may be considered a misplaced priority [63]. 
Domination of Fossil Fuel

South Africa relies heavily on its abundant coal and its abundant reserves to meet most of the required energy to run its economy principally in the large-scale power sector and energy-intensive coal mining industries. Approximately $60 \%$ of the coal produced is used in generating electricity, and around $25 \%$ of it is converted to fuel [3]. Locally, the low stocks of coal are consumed, while a portion of the high stocks, around 30\%, are exported. Coal represents the third-largest source of the country's foreign exchange, just after platinum and gold [12]. Globally, coal is regarded as one of the lowest sources of energy in terms of cost. Despite the enormous renewable energy potential that abounds in the country, there is no end in sight for the country to eradicate or become less dependent on its coal. This is because coal has stood as a strong bond in the country's economy with several policies, for now favoring its use, thereby impeding the dissemination of other imaginable energy alternatives. Discouraged by investors, more attention is given by policy and decision makers regarding short-term growth of the economy instead of long-term sustainable development [27].

\section{Incessant Court Cases}

There are several litigation hearings relating to the development of nuclear energy in South Africa. Numerous concerns raised regarding environmental issues and socioeconomic injustices have been a matter for court pronouncement. Some declaratory relief is being sought by the litigants concerning the nuclear procurement processes. Other cases involve public health issues as well as environmental impact assessment. These cases are considered as barriers to the development of nuclear energy in the country because the advancement of the technology is put on hold until final verdicts are pronounced by the different courts where the cases are being pursued [64].

\section{Porous Border System}

South Africa is the gateway to other countries, destinations mostly in the Southern Africa Development Communities (SADC), and has also been compounded with the influx of illegal migrants. These undocumented illegal migrants engage in different criminal activities such as illegal mining. Uranium, which is a by-product of nuclear energy, which can be mined for economic prosperity, can also be a dangerous weapon in the hands of criminals. A porous border system is a threat to the advancement of nuclear power. A case in point was when two women were caught with explosives worth over R1 million, which was destined to Gauteng Province from a neighboring country [65].

\subsection{Quantitative Analysis}

After the identification of the various factors under each quadrant, as presented supra, the experts were asked to assign weights to each criterion using the AHP approach, as presented above. The assigning of weights is key to enable policy and decision makers to know the most critical issues that require urgent attention during decision making relative to the development of a nuclear power plant. The experts provided vital perspectives to the successful completion of this research. In all, a total of 19 input criteria were assessed (pair comparison). The quantitative results for each section of the SWOT analysis are presented as follows.

Enabling laws and regulatory framework (S1). This factor is ranked highest by the experts; it recorded a weight of $39.2 \%$. This is, according to them, the safety of people and the environment in countries where NPP depends on the availability of a strong regulatory regime that oversees the safety of the facilities. In that regard, the IAEA promotes the formation of a comprehensive regulatory framework to safeguard the safety of such installations throughout its lifetime. These regulatory frameworks are made up of relevant regulations, legislation, and guidance as well as a robust management and leadership program for safe operations of the installation [66]. Additionally, in the view of the experts, South Africa already has these legislations and regulatory frameworks in place 
since it has an already operational nuclear facility. In that regard, the country already has experienced people in place to manage any further expansion that would take place, hence, the reason for the high score for this factor.

Uranium mining (S2). The availability of uranium placed second in the rankings; it recorded a weight of $21.9 \%$. Research has shown that the gold tailings at the Witwatersrand basin alone have an estimated uranium concentration of about $100 \mathrm{mg} / \mathrm{kg} \mathrm{U}_{3} \mathrm{O}_{8}$ averagely, which ranges from approximately $10 \mathrm{mg} / \mathrm{kg}$ to hundreds of $\mathrm{mg} / \mathrm{kg}$. As a result, these gold tailings are estimated to have more uranium or more uranium tailings from some mines in the country than those from Namibia or Germany [67]. South Africa has considerable uranium reserves with an extensive uranium mining industry. This makes the country one of the important world producers of uranium. The availability of this resource in the country is an important element of the security of energy supply in a country's energy sector [68].

Experience with the operations of an NPP and management of radioactive waste (S3). There has always been a strong awareness about the possible hazard of nuclear criticality as well as the release of radioactive materials from nuclear power plants. Due to this, there is always the need to get highly qualified personnel to manage and operate such facilities. South Africa has a running NPP and has some of the best personnel in the industry responsible for the operation and management of nuclear waste. This comes as an advantage relative to the country's intended vision of adding more NPPs to its energy generation mix. As a result, the experts assigned a weight of $13.7 \%$ to this factor.

Reduction in GHGs' emissions (S4). Experts assigned a weight of $10.8 \%$ to this factor. Obviously, nuclear power comes with advantages, one of which is the fact that nuclear energy has proven to deliver safe and considerable base-load power without generating large quantities of GHG. Therefore, increasing its use in the country's energy generation mix has the potential to cut down the level of emissions that are associated with the generation of power.

Strong partnerships' integration (S5). As discussed above, the South African government already has strong collaborations with several countries relative to its nuclear power development. International partnership is key to the success of innovative nuclear research and development activities relative to the sharing of financial burdens, prevention of duplications, optimization of the use of existing resources, enhancement in the movement of specialists and knowledge, and the exploitation of synergies. It is in light of this that it is important for countries that have expressed interest in the development of their first NPP to be encouraged to come together with international organizations to cooperate on innovative nuclear systems as well as the sharing of information on a broad cross-sector range, which may include the formation of clear corporation rules as well as coordination instruments within international bodies' framework, which include representatives from both industrial and governmental entities [69]. Given this, the consulted experts assigned a weight of $8.2 \%$ to this factor, placing it third in terms of the ranking. The government is, therefore, called upon to deepen its cooperation with both international industrial entities and governments.

High energy density (S6). Experts assigned a weight of $6.3 \%$ to this factor. As indicated supra, the high energy density of fuel used in NPPs makes it energy efficient. It is estimated that a 6-g uranium pellet has an energy that is equal to 17,000 cubic feet of natural gas or a ton of coal [70]. As a result, it comes as a form of minimizing environmental pollution relative to waste from the nuclear facility.

The outcome of the AHP for the strengths is presented in Figure 2. The consolidated matrix for the AHP is presented in Table 5. According to the results, a CR and GCI of $9 \%$ and 0.33 were obtained. This is an indication that the judgements of the consulted experts are consistent and reliable. 


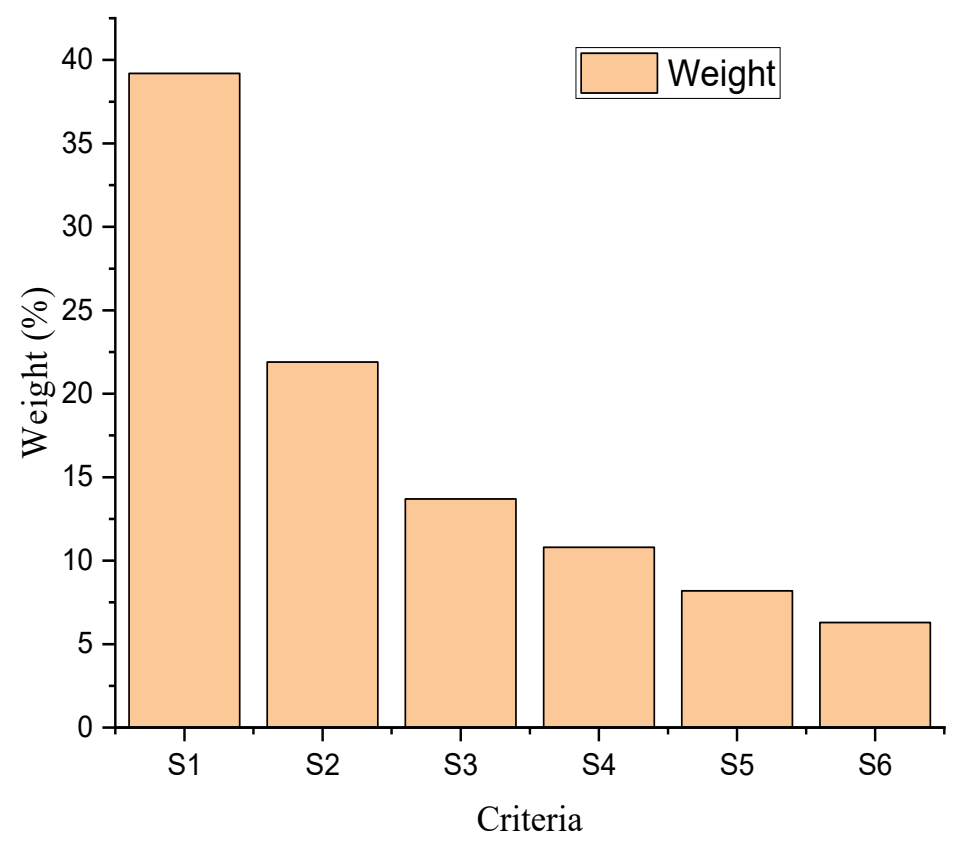

Figure 2. Weights for the various criteria under strengths.

Table 5. Pairwise comparison matrix for strengths.

\begin{tabular}{ccccccc}
\hline Criteria & S1 & S2 & S3 & S4 & S5 & S6 \\
\hline S1 & 1 & 3 & 5 & 3 & 4 & 3 \\
\hline S2 & $1 / 3$ & 1 & 3 & 3 & 2 & 3 \\
\hline S3 & $1 / 5$ & $1 / 3$ & 1 & 3 & 2 & 2 \\
\hline S4 & $1 / 3$ & $1 / 3$ & $1 / 3$ & 1 & 2 & 3 \\
\hline S5 & $1 / 4$ & $1 / 2$ & $1 / 2$ & $1 / 2$ & 1 & 2 \\
\hline S6 & $1 / 3$ & $1 / 3$ & $1 / 2$ & $1 / 3$ & $1 / 2$ & 1 \\
\hline
\end{tabular}

Costly to build and lengthy construction timeframe (W1). The cost of construction for NPP depends on several determinants. Some of these include the capacity of the plant and its complex technology, revisions during construction, safety, environmental concerns, modularization and serialization, change in standards for regulation during construction, and acts of nuclear opponents, which are all factors that affect the cost of construction of a NPP [71]. Financing of an NPP in the course of construction represents an additional layer of the entire investment costs, which depend on the construction period and the interest rate during construction. It has been estimated that the financing cost of an NPP may represent an extra $20-29 \%$ of the over-night cost for a construction period of 7 years and $37-57 \%$ of the overnight cost for an increased construction period to 10 years, when a Weighted Average Cost of Capital (WACC) between 7-10\% is applied, excluding the general price inflation rate [72]. This, according to the experts, is a major concern in the development of NPP, especially for a developing economy such as South Africa that may not be able to solely finance the construction of additional NPPs and may, therefore, rely on outsiders to fund it. In their view, this could prolong the construction period, which will ultimately result in an increased overnight cost for the power plant. To that effect, this factor was given the highest weightage of $50.47 \%$ among the identified weaknesses, making it the first priority.

Limited fuel availability (W2). The finite nature of nuclear fuel is one of the disadvantages, although there is a technology to recycle spent fuel for reuse. Even though South Africa has uranium deposits, as indicated earlier, there is still consent among the experts about a possible shortage of this resource in the future, which may mean that the country 
would have to depend on other countries to fuel its power plants. For this reason, the experts assigned a weight of $8.26 \%$ to it, which indicates that it is the last priority among the weaknesses. This was expected because, as indicated, there is a technology in place to close the fuel cycle.

Risks of nuclear accidents (W3). This is an issue that has always dominated discussions with the development of nuclear energy. The development of NPPs has mostly been characterized by public concerns due to the risk of accidents. These concerns became more global after the Fukushima Daiichi nuclear accident. As a result, countries such as Italy (in 1987), Sweden (in 1980), Taiwan (in 2018), and Switzerland (in 1990) used referenda to decide on their nuclear energy policies, i.e., whether to shut down or maintain NPPs [73]. Although several steps have been taken by manufacturers of the various components, especially the reactor core, to withstand a very high magnitude of earthquakes, the experts still apportioned $30.26 \%$ to this factor, placing it second in terms of ranking.

Inadequate manpower/technical know-how (W4). The availability of the required manpower and technical know-how is very key in the sector. According to the experts, although South Africa has experience in the nuclear energy sector, an addition of more power stations will demand more experienced hands. However, not many people are being trained to take over from the aging workers, although a few are being trained in countries such as Russia. They, therefore, see it as a weakness for the sector and, therefore, call on the government to invest more into the training of more young people in the sector. They assigned a weight of $11 \%$ to this weight, making it a third priority.

The consolidated results for the AHP are presented in Table 6, while the weights for the various criteria under the weaknesses section are represented in Figure 3. A CR and $\mathrm{GCI}$ of $3.9 \%$ and 0.14 were obtained for the AHP, putting it within the acceptable range.

Table 6. Consolidated pairwise matrix for weaknesses.

\begin{tabular}{ccccc}
\hline Criteria & W1 & W2 & W3 & W4 \\
\hline W1 & 1 & 5 & 2 & 5 \\
\hline W2 & $1 / 5$ & 1 & $1 / 3$ & $1 / 2$ \\
\hline $\mathrm{W} 3$ & $1 / 2$ & 3 & 1 & 4 \\
\hline $\mathrm{W} 4$ & $1 / 5$ & 2 & $1 / 4$ & 1 \\
\hline
\end{tabular}

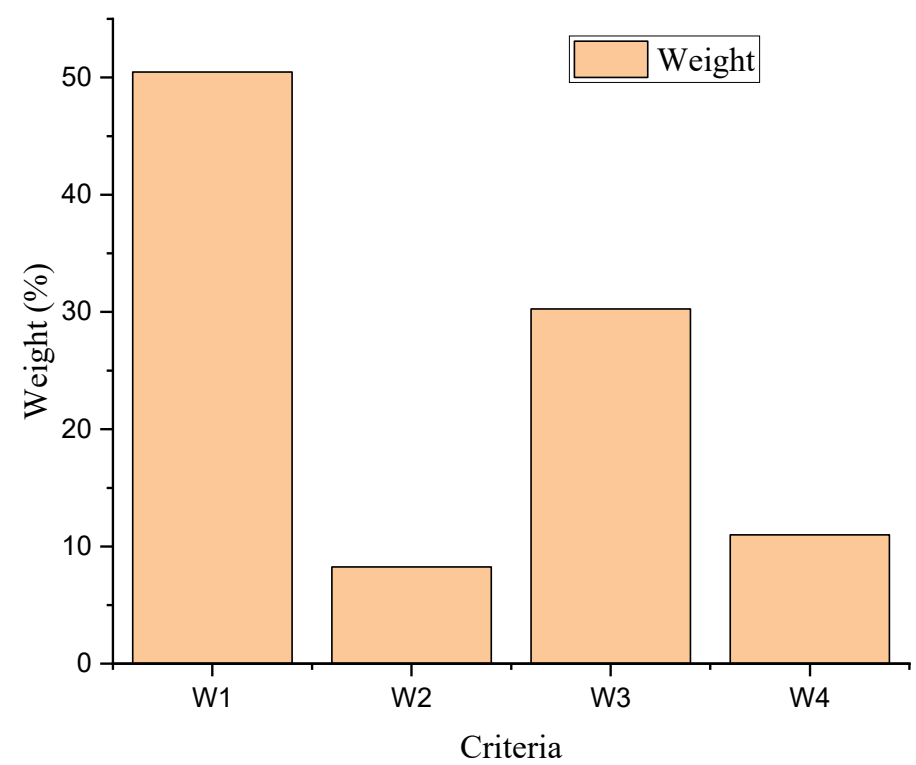

Figure 3. Weights for the weaknesses. 
Energy export and demand (O1). South Africa, through Eskom, which is its national electricity utility, remains the dominant electricity market in that enclave. Electricity systems of smaller countries such as Lesotho, Botswana, Swaziland, and Namibia, which are neighboring countries, were all developed as offshoots of the South African network, and, as a result, they have historically been importers of electrical power from South Africa [74]. With the South African Power Pool (SAPP), an expansion in the country's electricity-generating capacity, especially along the lines of nuclear energy, would have a large energy market in the sub-region [44]. This means power can be exported to other countries through the SAPP, and, as a result, a weight of $52.09 \%$ was assigned to this factor, indicating its relevance in the energy sector.

Climate change awareness (O2). The increasing threat of GHG emissions on the survival of people and the environment, in general, has led to renewed commitments by world leaders to find alternative sources of energy generation to meet demand $[37,75,76]$. Nuclear energy is seen globally as one of the options for energy generation that could help cut down the levels of GHG emissions. To that effect, it was ranked as the second-highest opportunity for the sector; it recorded a weight of $25.89 \%$.

Foreign investor's partnership (O3). Some 30 countries have been identified as emerging markets for nuclear energy technologies by the World Nuclear Association. These regions include the Middle East; Eastern Europe; central, western, northern, and southern Africa; Central and South America; and Southeast and East Asia. These markets have been identified by China and Russia as opportunities to enlarge their territories of influence through economic and diplomatic relationships [77]. This presents an opportunity to South Africa in terms of collaboration to help finance its nuclear power expansion drive. Other countries such as the USA and South Korea could also have an interest in South Africa's nuclear energy and could invest in the sector. Especially, considering that the South African government wants to add a total of $2.5 \mathrm{GW}$ of nuclear power to its generation mix, it is safe to say that small modular reactors (SMRs) may be the best choice in that regard. South Korea and the USA may have an ace in the hole for the development of SMRs, since the South African energy minister stated that the country was considering the development of modular stations [78]. Russia's ability to provide funding for new NPP projects through the country's state-owned enterprises enables it to provide attractive financial terms to newcomer countries in the nuclear energy sector [77]. The consulted specialists assigned a weight of $12.08 \%$ to this factor, meaning this factor ranks third in terms of opportunities in the sector.

Job creation potentials $(\mathbf{O} 4)$. As presented supra, the development of nuclear energy comes with several job opportunities and, considering the high unemployment rate among the youths in the country, an expansion in nuclear energy would provide jobs for some people. Experts, therefore, apportioned a $9.94 \%$ weightage to this factor.

A GCI and CR of 0.29 and $8.2 \%$, respectively, were obtained from the computations. The weights and consolidated matrix are indicated in Figure 4 and Table 7, respectively.

Table 7. Pairwise comparison matrix for opportunities.

\begin{tabular}{cccccc}
\hline Criteria & W1 & W2 & W3 & W4 \\
\hline W1 & 1 & 3 & 5 & 3 \\
\hline $\mathrm{W} 2$ & $1 / 3$ & 1 & 3 & 3 \\
\hline $\mathrm{W} 3$ & $1 / 5$ & $1 / 3$ & 1 & 2 \\
\hline $\mathrm{W} 4$ & $1 / 3$ & $1 / 3$ & $1 / 2$ & 1 \\
\hline
\end{tabular}




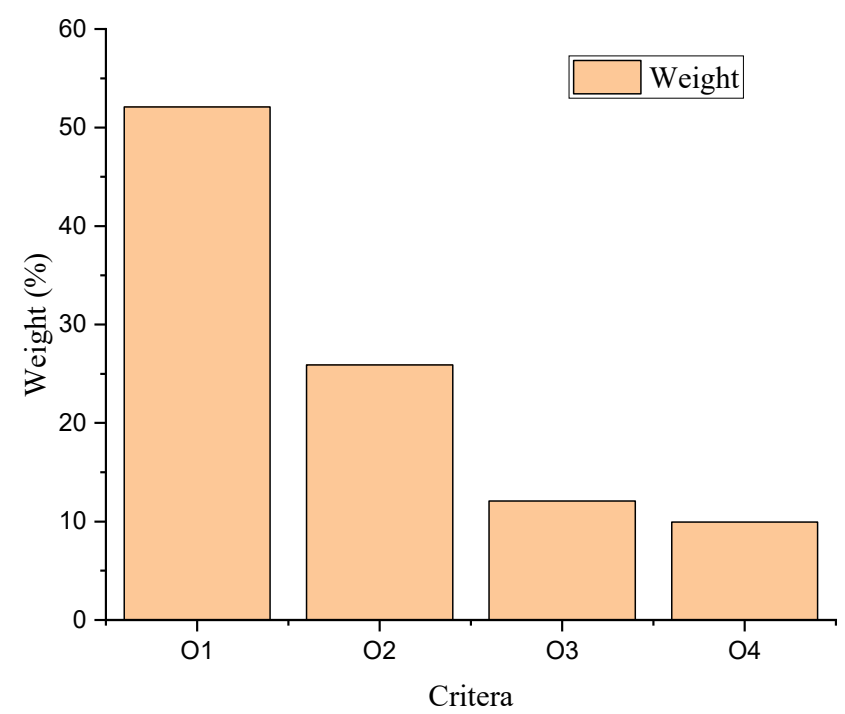

Figure 4. Weight for the identified opportunities in the sector.

Seismic events (T1). The importance of a nuclear facility to withstand earthquakes has proven to be very key for its safety. An NPP must be designed using the 'defense-indepth' principle, which involves a systematic application of consecutive and independent levels of protection through the combination of box-in-box physical barriers and redundant as well as a different protection functions with accident management procedures. In this case, one protection layer comes into play when the other fails [79]. These are all measures that are currently employed to minimize the effect of nuclear accidents that may be caused by seismic events. However, despite all these measures that are put in place to enhance the safety of NPPs, the experts still assigned the highest weight, of $42.5 \%$, to it. It is still seen as a major threat to the development of NPPs.

Water availability (T2). The installation of new NPPs normally comes with extra water demands for cooling purposes, mostly freshwater. Research has shown that NPPs' water consumption is highest in terms of per MWh among the thermoelectric technologies [80]. Considering the water challenges in the country, as presented in earlier discussions, the experts assigned a weight of $14 \%$ to this factor, which is indicative of the very important role the availability of water at a locality has on site-selection decisions for NPP installations.

Domination of fossil fuel (T3). The dominance of fossil fuel in the generation of energy to meet the increasing demands has always been a major threat to the diversification of the energy sector. This is even more worsened by people in authority with interest in the fossil fuel industry. Such situations tend to slow down the implementation of policies that would have otherwise led to the diversification of the energy sector. A weight of $27.1 \%$ was assigned to this factor, placing it second in terms of the threats in the sector. It is the view of the experts that the dominance of fossil fuels in the country's energy mix would not give any sense of urgency to authorities to speed up the processes that would lead to the expansion of the nuclear energy industry in the country since the country has abundant coal reserves.

Incessant court cases (T4). The usual opposition from the citizenry relative to the development of nuclear facilities is also a major hurdle that the South African government would have to cross relative to its nuclear energy expansion agenda. Both community and public acceptance play a major role in assessing the social sustainability of energy policy. However, the presence of NIMBY, i.e., not in my backyard, among the people could result in noticeable differences among the community and public acceptance [76]. Research has shown that the attitudes of people towards energy technologies are determined by their net perception of the benefits or risks of that technology, and this is influenced by the following factors: psychological, personal, and contextual factors [81]. Psychological factors involve factors such as familiarity or the level of knowledge about the technology in question and the level of trust. Issues relating to personal factors include sociodemographic 
characteristics such as gender, age, and social class. Contextual factors include the spatial proximity to the energy facility, the technological aspects, and public engagement $[81,82]$. The South African government would have to devise appropriate mechanisms to engage with all stakeholders and the general populace to educate them on nuclear energy. This could help reduce the level of dislike and opposition expressed by sections of the people. To that effect, a weight of $5.8 \%$ was assigned to this factor during the survey.

Porous border system (T5). The security of the power plant is key. Therefore, anything that makes it easier for a country to be infiltrated by foreigners is a major concern. As already indicated earlier, the country is surrounded by many countries whose citizens and non-citizens can easily enter South Africa through illegal routes. This is a major concern, according to the experts, and, as a result, a weight of $10.6 \%$ was assigned, which shows the severity of this problem. According to the experts, the government must tackle the issue of illegal migrants seriously to keep the country safe to protect facilities such as NPPs.

From the computations, a CR of $8.1 \%$ and a GCI of 0.29 were obtained. The consolidated matrix for the threats is presented in Table 8, while the weights for the various criteria are also presented in Figure 5.

Table 8. Pairwise comparison matrix for the identified threats.

\begin{tabular}{cccccc}
\hline Criteria & T1 & T2 & T3 & T4 & T5 \\
\hline $\mathrm{T} 1$ & 1 & 5 & 2 & 7 & 2 \\
\hline $\mathrm{T} 2$ & $1 / 5$ & 1 & $1 / 3$ & 2 & 3 \\
\hline $\mathrm{T} 3$ & $1 / 2$ & 3 & 1 & 4 & 3 \\
\hline $\mathrm{T} 4$ & $1 / 7$ & $1 / 2$ & $1 / 4$ & 1 & $1 / 2$ \\
\hline $\mathrm{T} 5$ & $1 / 2$ & $1 / 3$ & $1 / 3$ & 2 & 1 \\
\hline
\end{tabular}

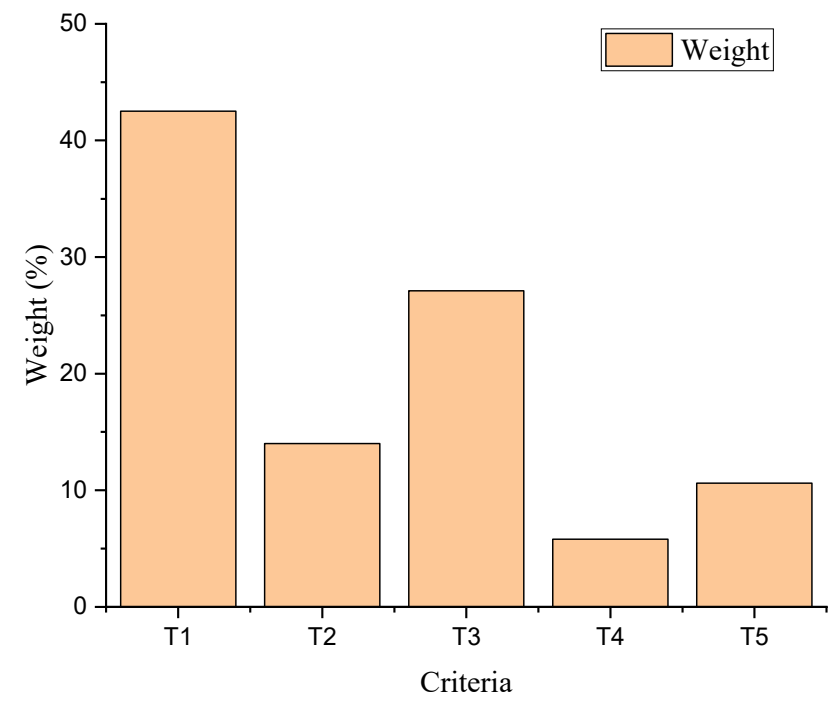

Figure 5. Weights for the various threats.

\section{Conclusions}

There is the prospect of South Africa mitigating its energy difficulties from nuclear sources due to the recurrent power crisis resulting from the aging of its coal-fired plants. Nuclear energy is potentially viable in the country and can meet the high energy demand while also creating room for a feasible and sustainable transition to the decarbonization of the present energy carrier, which is heavily dependent on coal. Although, for decades, coal has dominated the country's energy market as a threat to the consideration of other sources of energy, with the government energy mix generation target by 2030, this offers a very conducive entry for nuclear energy. The decision of the government to add other 
alternative energy sources to mitigate the impact of the continuous power outrange, which has led to the persistent load shedding in the country, is a welcome idea. Among the considered energy mix is the integration of nuclear energy. This article, thus, evaluated the country preparedness of its nuclear power program using a combination of SWOT analysis and AHP tool. The findings from the study evaluation show that the strengths of incorporating nuclear energy in the country nuclear power program are its enabling laws and regulatory framework, uranium mining, and strong partnerships' integration, which placed the country in a better position to implement a nuclear power program. Similarly, the associated weaknesses to the development of nuclear power production in the country are the inadequate manpower/technical know-how, incessant court cases, and porous border system that can be mitigated. For instance, the management of a nuclear power plant comes with a lot of responsibilities and, thus, there is a need for an experienced workforce to handle such a facility. Though regarded as a weakness in this study, the training of specialists for the nuclear power sector is a leverage to the strength, as continuous performance assessment of the country workforce is necessary. Additionally, incessant court cases can be addressed as well as the porous border system. The opportunities to have robust nuclear energy production abound in South Africa, particularly because of the present demand for energy in the country and also to generate more GDP through energy exportation. Climate change awareness is paramount in the country due to the impact of fossil fuel consumption. The foreign investment partnership has been expressed by interested countries to partner with the government in advancing the prospect of the technology. The key associated threats regarding nuclear power in the country can also be improved, except for natural disasters, which can only be managed. There is, however, the need to reassure society that the introduction of nuclear energy will not lead to the proliferation of arms and dangerous weapons. The study recommends that the government further capitalize on its strengths and opportunities, while developing a policy plan can help diminish the weaknesses and threats.

Author Contributions: Conceptualization S.E.U., E.B.A. and O.S.D. Methodology, E.B.A., S.E.U., T.S.A. and O.S.D.; Writing—original draft preparation: S.E.U., E.B.A., O.S.D., K.S., N.S.N., G.-I.E.E. and T.S.A.; Writing-review and editing: S.E.U., E.B.A., O.S.D., K.S., N.S.N., G.-I.E.E. and T.S.A. All authors have read and agreed to the published version of the manuscript.

Funding: This research received no external funding.

Institutional Review Board Statement: Not applicable.

Informed Consent Statement: Not applicable.

Data Availability Statement: Data sharing is not applicable.

Acknowledgments: The authors acknowledge with thanks the Centre for Postgraduate Studies and the Postdoctoral Fellowship/Research Committee of the Cape Peninsula University of Technology, and the Directorate of Research and Innovations of the University of Venda.

Conflicts of Interest: The authors declare no conflict of interest.

\section{References}

1. World Bank. World Development Indicators 2020. Available online: https:/ / data.worldbank.org/ (accessed on 2 April 2021).

2. Baloch, M.H.; Kaloi, G.S.; Memon, Z.A. Current scenario of the wind energy in Pakistan challenges and future perspectives: A case study. Energy Rep. 2016, 2, 201-210. [CrossRef]

3. Department of Energy. State of Renewable Energy in South Africa 2015. Available online: http://www.energy.gov.za/files/ media/Pub/2017-State-of-Renewable-Energy-in-South-Africa.pdf (accessed on 28 August 2021).

4. Statistics South Africa. General Household Survey; Statistics South Africa: Pretoria, South Africa, 2020; pp. 1-192.

5. Wright, J.G.; Bischof-Niemz, T.; Calitz, J.R.; Mushwana, C.; van Heerden, R. Long-term electricity sector expansion planning: A unique opportunity for a least cost energy transition in South Africa. Renew. Energy Focus 2019, 30, 21-45. [CrossRef]

6. Alden, C.; Schoeman, M. South Africa's symbolic hegemony in Africa. Int. Politics 2015, 52, 239-254. [CrossRef]

7. Jawerth, N. What is the clean energy transition and how does nuclear power fit in? IAEA Bull. 2020, 61, 4-5.

8. IEA. World Energy Outlook 2019-Analysis; IEA: Paris, France, 2019. 
9. Ishola, F.A.; Olatunji, O.O.; Ayo, O.O.; Akinlabi, S.A.; Adedeji, P.A.; Inegbenebor, A.O. Sustainable Nuclear Energy Exploration in Nigeria-A SWOT Analysis. Procedia Manuf. 2019, 35, 1165-1171. [CrossRef]

10. Agyekum, E.B.; Ansah, M.N.S.; Afornu, K.B. Nuclear energy for sustainable development: SWOT analysis on Ghana's nuclear agenda. Energy Rep. 2020, 6, 107-115. [CrossRef]

11. DMR (Department of Mineral Resources). Annual Report 2015/2016; Deparment of Mineral Resources: Pretoria, South Africa, 2016; pp. 1-198.

12. DOE. South African Energy Sector Report 2019; Deparment of Energy: Pretoria, South Africa, 2019.

13. Eskom. Integrated Results 2019. Available online: https://www.eskom.co.za/IR2019/Pages/default.aspx (accessed on 28 August 2021).

14. DMRE. Nuclear Department: Energy Republic of South Africa 2020. Available online: http:/ / www.energy.gov.za/files/esources/ nuclear/nuclear_back.html (accessed on 8 October 2021).

15. Thomas, S. PBMR: Hot or Not?-Nuclear Engineering International. Available online: https://www.neimagazine.com/features/ featurepbmr-hot-or-not (accessed on 27 October 2021).

16. Nuclear Engineering International. South Africa Cancels PBMR Funding-Nuclear Engineering International. Available online: https:/ / www.neimagazine.com/news/newssouth-africa-cancels-pbmr-funding (accessed on 27 October 2021).

17. POWER. South Africa Abandons Pebble Bed Modular Reactor Project. POWER Magazine, 22 September 2010. Available online: https:/ / www.powermag.com/south-africa-abandons-pebble-bed-modular-reactor-project/ (accessed on 27 October 2021).

18. South African Government. Let's Grow South Africa Together 2020. Available online: https:/ / www.gov.za/ (accessed on 28 August 2021).

19. Meierding, E. Energy security and sub-Saharan Africa. Inst. Dev. Policy Rev. Intern. Politique Dev. $2011,2,2$.

20. Is Africa Ready for Nuclear Energy? 2018. Available online: https://www.iaea.org/newscenter/news/is-africa-ready-fornuclear-energy (accessed on 28 August 2021).

21. Ramana, M.V.; Agyapong, P. Thinking big? Ghana, small reactors, and nuclear power. Energy Res. Soc. Sci. 2016, 21, 101-113. [CrossRef]

22. Mari, C. The costs of generating electricity and the competitiveness of nuclear power. Prog. Nucl. Energy 2014, 73, $153-161$. [CrossRef]

23. Terrados, J.; Almonacid, G.; Hontoria, L. Regional energy planning through SWOT analysis and strategic planning tools: Impact on renewables development. Renew. Sustain. Energy Rev. 2007, 11, 1187-1275. [CrossRef]

24. Kamran, M.; Fazal, M.R.; Mudassar, M. Towards empowerment of the renewable energy sector in Pakistan for sustainable energy evolution: SWOT analysis. Renew. Energy 2020, 146, 543-558. [CrossRef]

25. Chen, W.-M.; Kim, H.; Yamaguchi, H. Renewable energy in eastern Asia: Renewable energy policy review and comparative SWOT analysis for promoting renewable energy in Japan, South Korea, and Taiwan. Energy Policy 2014, 74, 319-329. [CrossRef]

26. Hamami, S.; Aloui, H.; Chaker, N.; Neji, R. SWOT analysis: Tunisian energy system. In Proceedings of the IREC2015: The Sixth International Renewable Energy Congress, Sousse, Tunisia, 24-26 March 2015; pp. 1-6. [CrossRef]

27. Lei, Y.; Lu, X.; Shi, M.; Wang, L.; Lv, H.; Chen, S.; Hu, C.; Yu, Q.; Dias, S.; da Silveira, H. SWOT analysis for the development of photovoltaic solar power in Africa in comparison with China. Environ. Impact Assess. Rev. 2019, 77, 122-127. [CrossRef]

28. Saaty, T.L. How to make a decision: The Analytic Hierarchy Process. Eur. J. Oper. Res. 1990, 48, 9-26. [CrossRef]

29. Saaty, T.L. What is the Analytic Hierarchy Process? In Mathematical Models for Decision Support; Mitra, G., Greenberg, H.J., Lootsma, F.A., Rijkaert, M.J., Zimmermann, H.J., Eds.; Springer: Berlin/Heidelberg, Germany, 1988; pp. 109-121. [CrossRef]

30. Alami, M.A.; Elwali, E.F.; Ghennioui, A.; Mezrhab, A.; Mezrhab, A. A GIS-AHP combination for the sites assessment of large-scale CSP plants with dry and wet cooling systems. Case Study East. Morocco. Sol. Energy 2018, 166, 2-12. [CrossRef]

31. Agyekum, E.B.; Amjad, F.; Mohsin, M.; Ansah, M.N.S. A bird's eye view of Ghana's renewable energy sector environment: A Multi-Criteria Decision-Making approach. Util. Policy 2021, 70, 101219. [CrossRef]

32. Ali, E.B.; Agyekum, E.B.; Adadi, P. Agriculture for Sustainable Development: A SWOT-AHP Assessment of Ghana's Planting for Food and Jobs Initiative. Sustainability 2021, 13, 628. [CrossRef]

33. Goepel, K.D. Implementing the Analytic Hierarchy Process as a Standard Method for Multi-Criteria Decision Making in Corporate Enterprises-A New AHP Excel Template with Multiple Inputs. 2013. Available online: https:/ / doi.org/10.13033/isahp.y2013. 047 (accessed on 23 September 2021).

34. Goepel, K.D. New AHP Excel Template with Multiple Inputs-BPMSG. Available online: https://bpmsg.com/new-ahp-exceltemplate-with-multiple-inputs / (accessed on 19 July 2021).

35. Goepel, K.D. Implementation of an Online Software Tool for the Analytic Hierarchy Process (AHP-OS). Int. J. Anal. Hierarchy Process. 2018, 10, 3. [CrossRef]

36. Agyekum, E.B.; Amjad, F.; Shah, L.; Velkin, V.I. Optimizing photovoltaic power plant site selection using analytical hierarchy process and density-based clustering-Policy implications for transmission network expansion, Ghana. Sustain. Energy Technol. Assess. 2021, 47, 101521. [CrossRef]

37. Amjad, F.; Agyekum, E.B.; Shah, L.A.; Abbas, A. Site location and allocation decision for onshore wind farms, using spatial multi-criteria analysis and density-based clustering. A techno-economic-environmental assessment, Ghana. Sustain. Energy Technol. Assess. 2021, 47, 101503. [CrossRef] 
38. Agyekum, E.B.; Amjad, F.; Aslam, F.; Ali, A. Application of Weighted Linear Combination approach in a Geographical Information System environment for nuclear power plant site selection: The case of Ghana. Ann. Nucl. Energy 2021, 162, 108491. [CrossRef]

39. Elbaradei, M.; Nwogugu, E.; Rames, J. International law and nuclear energy: Overview of the legal framework. IAEA Bull. 1995, $37,16-25$.

40. National Nuclear Regulator. 8th National Report by South Africa on the Convention on Nuclear Safety; Deparment of Energy: Pretoria, South Africa, 2019.

41. Gielen, D.; Boshell, F.; Saygin, D.; Bazilian, M.D.; Wagner, N.; Gorini, R. The role of renewable energy in the global energy transformation. Energy Strategy Rev. 2019, 24, 38-50. [CrossRef]

42. Dill, S.; Boer, R.H.; Boshoff, H.J.J.; James, A.R.; Stobart, B.I. An Assessment of the Impacts of Groundwater Quality Associated with the Backfilling of Dolomitic Cavities with Gold Mine Tailings; Water Research Commission: Pretoria, South Africa, 2007.

43. Sah, A.; Lovering, J.; Maseli, O.; Saxena, A. Atoms for Africa: Is There a Future for Civil Nuclear Energy in Sub-Saharan Africa? CGD Policy Pap. 2018, 124, 1-27.

44. Ansah, M.N.S.; Agyekum, E.B.; Amoah, P.A.; Afornu, B.K. Atoms for electricity generation in Africa: Analysis of factors affecting the continent's readiness. Prog. Nucl. Energy 2021, 141, 103938. [CrossRef]

45. Bruckner, T.; Bashmakov, I.A.; Mulugetta, Y.; Chum, H.; De la Vega Navarro, A.; Edmonds, J.; Faaij, A.; Fungtammasan, B. Chapter 7-Energy Systems. In Climate Change 2014: Mitigation of Climate Change. IPCC Working Group III Contribution to AR5; Cambridge University Press: Cambridge, UK, 2014.

46. Davidson, O.; Winkler, H. South Africa's energy futures: Visions, driving factors and sustainable development indicators. In Report for Phase 1 of the Sustainable Development and Climate Project; Energy \& Development Research Centre, University of Cape Town: Cape Town, South Africa, 2003.

47. World Nuclear Association. South African Nuclear Energy. Available online: https://www.world-nuclear.org/informationlibrary / country-profiles/countries-o-s/south-africa.aspx (accessed on 6 February 2021).

48. Lane, C.; Nuclear Energy Pros and Cons. Solar Reviews 2021. Available online: https://www.solarreviews.com/content/blog/ nuclear-energy-pros-and-cons (accessed on 8 October 2021).

49. Spring Power and Gas. The Pros E Cons of Nuclear Energy: Is It Safe? Spring Power \& Gas: Harrisburg, PA, USA, 2018; Available online: https:/ / springpowerandgas.us/the-pros-cons-of-nuclear-energy-is-it-safe/ (accessed on 8 October 2021).

50. Luderer, G.; Krey, V.; Calvin, K.; Merrick, J.; Mima, S.; Pietzcker, R.; Van Vliet, J.; Wada, K. The role of renewable energy in climate stabilization: Results from the EMF27 scenarios. Clim. Chang. 2014, 123, 427-441. [CrossRef]

51. Sovacool, B.K. A Critical Evaluation of Nuclear Power and Renewable Electricity in Asia. J. Contemp. Asia 2010, 40, 369-400. [CrossRef]

52. Shang, D.; Geissler, B.; Mew, M.; Satalkina, L.; Zenk, L.; Tulsidas, H.; Barkerd, L.; El-Yahyaoui, A.; Hussein, A.; Taha, M.; et al. Unconventional uranium in China's phosphate rock: Review and outlook. Renew. Sustain. Energy Rev. 2021, $140,110740$. [CrossRef]

53. Kushida, K.E. The Fukushima Nuclear Disaster and the Democratic Party of Japan: Leadership, Structures, and Information Challenges During the Crisis. Jpn. Political Econ. 2014, 40, 29-68. [CrossRef]

54. Savaresi, A. The role of REDD in the harmonisation of overlapping international obligations. In Climate Change and the Law; Springer: Berlin/Heidelberg, Germany, 2013; pp. 391-418.

55. Gujba, H.; Thorne, S.; Mulugetta, Y.; Rai, K.; Sokona, Y. Financing low carbon energy access in Africa. Energy Policy 2012, 47, 71-78. [CrossRef]

56. IAEA. Nuclear Power and Sustainable Development; IAEA: Vienna, Austria, 2016.

57. Linzer, L.M.; Bejaichund, M.; Cichowicz, A.; Durrheim, R.J.; Goldbach, O.D.; Kataka, M.O.; Kijko, A.; Milev, A.M.; Saunders, I.; Spottiswoode, S.M.; et al. Recent research in seismology in South Africa: IUGG report. S. Afr. J. Sci. 2007, 103, 419-426. [CrossRef]

58. Douglas, I. Flooding in African cities, scales of causes, teleconnections, risks, vulnerability and impacts. Int. J. Disaster Risk Reduct. 2017, 26, 34-42. [CrossRef]

59. Rautenbach, C.; Daniels, T.; de Vos, M.; Barnes, M.A. A coupled wave, tide and storm surge operational forecasting system for South Africa: Validation and physical description. Nat. Hazards 2020, 103, 1407-1439. [CrossRef]

60. Mathinya, V.N.; Rensburg, L.D.; van Mavimbela, S.S.W.; Barnard, J.H. Malt Barley (hordeum Vulgare L.) Water Use and Grain Yield Response to Saline Irrigation Under Shallow Groundwater Table Conditions. Irrig. Drain. 2019, 68, 867-880. [CrossRef]

61. World Commission on Dams. Dams and Development: A New Framework for Decision-Making Overview of the Report by the World Commission on Dams; Earthscan Publications Ltd.: London, UK, 2001.

62. Berry, K. Background Paper Latin America: Nuclear Facts and Figures. International Collaboration for the Development of Neutron Detectors. 2009. Available online: http://www.icnnd.org/research/index.html (accessed on 26 September 2021).

63. Crookes, C.; Hedden, S.; Donnenfeld, Z. A delicate balance: Water scarcity in South Africa. ISS S. Afr. Rep. 2018, $2018,1-24$.

64. Earthlife Africa, Environment Institute. Review Application; Groundup: Cape Town, South Africa, 2017.

65. Women Who "Smuggled R1m Worth of Explosives into SA" to Stay Behind Bars. TimesLIVE. Available online: https: / / www.timeslive.co.za/news/south-africa / 2020-02-14-women-who-smuggled-r1m-worth-of-explosives-into-sa-to-staybehind-bars / (accessed on 4 September 2021).

66. IAEA. Nuclear Installations 2016. Available online: https:/ / www.iaea.org/topics/nuclear-installations (accessed on 21 September 2021). 
67. Winde, F.; Geipel, G.; Espina, C.; Schüz, J. Human exposure to uranium in South African gold mining areas using barber-based hair sampling. PLoS ONE 2019, 14, e0219059. [CrossRef] [PubMed]

68. Nuclear Department: Energy Republic of South Africa. Available online: http://www.energy.gov.za/files/esources/nuclear/ nuclear_safety.html (accessed on 21 September 2021).

69. Innovation in Nuclear Energy Technology; OECD Nuclear Energy Agency (Ed.) Nuclear Energy Agency, Organisation for Economic Co-operation and Development: Paris, France, 2007.

70. Feng, L. Research on Nuclear Energy and Fossil Fuels in China. IOP Conf. Ser. Earth Env. Sci. 2021, 621, 012068. [CrossRef]

71. Carajilescov, P.; Moreira, J.M.L. Construction time of PWRs. In Proceedings of the 2011 International Nuclear Atlantic ConferenceINAC 2011, Belo Horizonte, Brazil, 24-28 October 2011.

72. European Commission. Nuclear Illustrative Programme Presented under Article 40 of the Euratom Treaty for the Opinion of the European Economic and Social Committee; European Commission: Brussels, Belgium, 2016.

73. Chung, J.-B. Public deliberation on the national nuclear energy policy in Korea-Small successes but bigger challenges. Energy Policy 2020, 145, 111724. [CrossRef]

74. ESMAP, South African Power Pool (SAPP). Transmission \& Trading Case Study; Economic Consulting AssociatesLimited: London, UK, 2009.

75. Adebayo, T.S.; Awosusi, A.A.; Oladipupo, S.D.; Agyekum, E.B.; Jayakumar, A.; Kumar, N.M. Dominance of Fossil Fuels in Japan's National Energy Mix and Implications for Environmental Sustainability. Int. J. Environ. Res. Public Health 2021, $18,7347$. [CrossRef]

76. Agyekum, E.B.; Ali, E.B.; Kumar, N.M. Clean Energies for Ghana-An Empirical Study on the Level of Social Acceptance of Renewable Energy Development and Utilization. Sustainability 2021, 13, 3114. [CrossRef]

77. Gordon, J. International Co-Financing of Nuclear Reactors between the United States and Its Allies-Atlantic Council 2020 Available online: https: / / www.atlanticcouncil.org/in-depth-research-reports/issue-brief/international-co-financing-of-nuclearreactors-between-the-united-states-and-its-allies / (accessed on 3 October 2021).

78. Proctor, D. Russia, China Drive Africa's Plan for Nuclear Expansion. POWER Magazine, 1 July 2020. Available online: https: / / www.powermag.com/russia-china-drive-africas-plan-for-nuclear-expansion/ (accessed on 3 October 2021).

79. Katona, T.J. Safety of Nuclear Power Plants with Respect to the Fault Displacement Hazard. Appl. Sci. 2020, 10, 3624. [CrossRef]

80. Sesma-Martín, D. Cooling Water: A Source of Conflict in Spain, 1970-1980. Sustainability 2020, 12, 4650. [CrossRef]

81. Sugiawan, Y.; Managi, S. Public acceptance of nuclear power plants in Indonesia: Portraying the role of a multilevel governance system. Energy Strategy Rev. 2019, 26, 100427. [CrossRef]

82. Finucane, M.L.; Alhakami, A.; Slovic, P.; Johnson, S.M. The affect heuristic in judgments of risks and benefits. J. Behav. Decis. Mak. 2000, 13, 1-17. [CrossRef] 